\title{
POST-WEANING VOLUNTARY FOOD INTAKE OF PIGS WEANED AT 2 OR 4 WEEKS OF AGE
}

\section{K. J. McCRACKEN}

Food and Agricultural Chemistry Research Division, Department of Agriculture, Newforge Lane, Belfast BT9 5PX

\section{INTRODUCTION}

I is generally recognized that pigs suffer a growth check associated with low voluntary food intake in the immediate post-weaning period and there is a tendency to assume that this is more severe with earlier weaning. However, apart from the study of McCracken (1980) on pigs weaned at 10 days of age and that of Robertson, Clarke and Bruce (1985) on singly caged pigs weaned at 21 days of age, there is little information on the time course for changes in food intake post weaning. The results given below relate to the pigs used by McCracken and Gray (1984) to study critical temperature.

\section{MATERIAL AND METHODS}

In experiment 1 , six litters weaned at 14 days were studied for 22 days. They were obtained from the Agricultural Research Institute, Hillsborough and standardized to nine pigs per litter by culling very light or heavy pigs. Each litter was kept in a tiered cage or metabolism crate for alternate $3 / 4$ day periods and fed to appetite three times per day to minimize food spillage. The diet contained $(\mathrm{g} / \mathrm{kg})$, ground flaked maize $317 \cdot 5$, dried skim milk 280 , fatted skim milk ( $400 \mathrm{~g}$ fat per $\mathrm{kg}$ ) 140 , fish meal 120 , sucrose 100 , groundnut oil 40 , trace minerals/vitamins $2 \cdot 5$. The analysis (dry-matter basis) was, crude protein $240 \mathrm{~g} / \mathrm{kg}$, metabolizable energy (ME) $18 \cdot 3 \mathrm{MJ} / \mathrm{kg}$.

In experiment 2 , six litters were weaned at 28 days and studied for 16 days. They were obtained from Greenmount Agricultural College and were standardized to six pigs per litter to maintain an acceptable floor space per pig. The cages and feeding regimen were the same as in experiment 1 . The diet contained $(\mathrm{g} / \mathrm{kg})$ ground flaked maize 250 , ground wheat $162 \cdot 5$, ground barley 100 , fatted skim milk ( $250 \mathrm{~g}$ fat $/ \mathrm{kg}$ ) 150 , fish meal 100 , soya 175 , sucrose 25 , soya-bean meal ( $480 \mathrm{~g}$ crude protein per $\mathrm{kg}$ ), fat concentrate 25 , calcium dihydrogen phosphate 10 , trace minerals/vitamins $2 \cdot 5$. The determined analysis was, crude protein $230 \mathrm{~g} / \mathrm{kg}$, ether extract $108 \mathrm{~g} / \mathrm{kg}, \mathrm{ME}$ $17 \cdot 2 \mathrm{MJ} / \mathrm{kg}$.
All food refusals were measured daily on a dry-matter basis. Spilt food and excreta were bulked for 3- or 4-day periods and used to calculate actual ME intake. The daily intakes were calculated on a pro rata basis within a $3 / 4$ day period in relation to apparent daily food consumption. All pigs were weighed once daily around $09.00 \mathrm{~h}$ prior to the morning feed. No significant scour problems were encountered in either experiment.

\section{RESULTS}

In experiment 1 , initial weights ranged from $2 \cdot 8$ to 6.5 (mean 4.4 ) $\mathrm{kg}$ and final weights after 22 days ranged from 7.5 to 15.6 (mean 11.0) $\mathrm{kg}$. ME intake increased rapidly to approximately $2 \cdot 3 \mathrm{MJ}$ per pig by day 4 after weaning, remained static until day 8 and then increased rapidly to a mean value of $12 \cdot 8 \mathrm{MJ} /$ day by day 22 . When $\mathrm{ME}$ intake was expressed per $\mathrm{kg}$ live weight or per $\mathrm{kg}$ $\mathrm{M}^{0.75}$, the 4- to 8-day plateau values averaged 450 and $710 \mathrm{~kJ}$ respectively (Figure 1). By day 22 the values had risen to 1150 and $2150 \mathrm{~kJ}$ respectively.

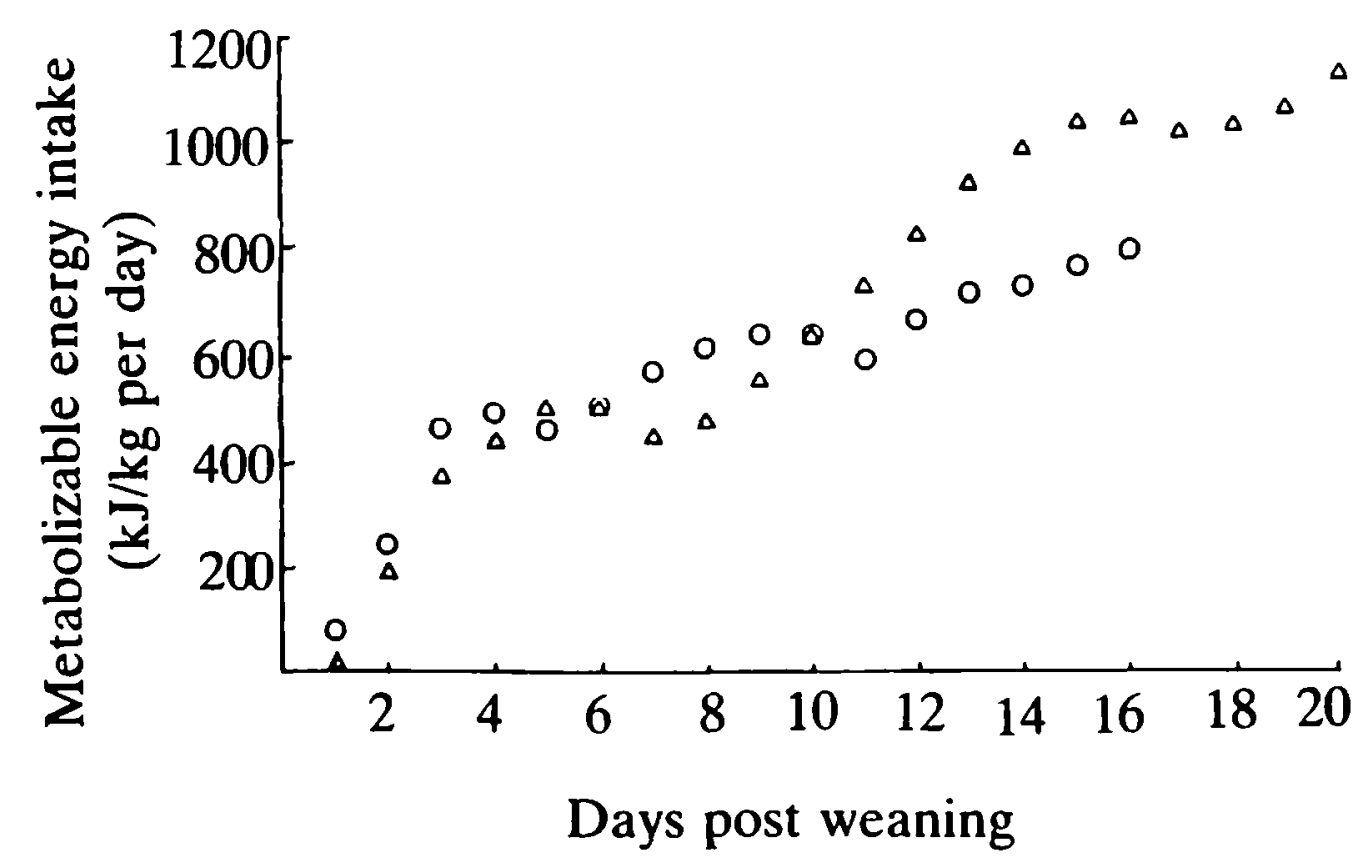

Fig. 1. Post-weaning (kJ/kg per day) of pigs weaned at 14 days $(\Delta)$ or 28 days $(\mathrm{O})$. 
In experiment 2 , initial weights ranged from $5 \cdot 2$ to $9 \cdot 8$ (mean $7 \cdot 0$ ) $\mathrm{kg}$ and final weights after 16 days ranged from 9.5 to 17.0 (mean 12.8 ) $\mathrm{kg}$. Daily ME intake increased rapidly to $3.8 \mathrm{MJ}$ per pig by day 4 . The plateau was slightly shorter (only 3 days) than in experiment 1 . During the subsequent 10-day period the mean ME intake increased steadily to $9 \cdot 8 \mathrm{MJ} / \mathrm{day}$. When expressed per $\mathrm{kg}$ live weight or per $\mathrm{kg} \mathrm{M}^{0.75}$, the plateau values averaged 480 and $810 \mathrm{~kJ}$ respectively (Figure 1 ) similar to those observed in experiment 1 . By day 16 the values had risen to 780 and $1470 \mathrm{~kJ}$ in comparison to values of 1030 and $1660 \mathrm{~kJ}$ respectively by day 16 in experiment 1 . The absolute growth rates in experiment 1 and experiment 2 respectively were 216 and $359 \mathrm{~g} /$ day. When expressed as a proportion of initial weight the values were 49.0 and $51.1 \mathrm{~g} /$ day per $\mathrm{kg}$ initial weight. During the last 8 days, i.e. from $7 \mathrm{~kg}$ live weight the experiment 1 pigs averaged $500 \mathrm{~g} /$ day.

\section{DISCUSSION}

The pattern of change of food intake, including the plateau observed at day 4 , was essentially similar in the two experiments. Since the sources of pigs and the diets used were different it is not possible to draw firm conclusions about the effect of weaning age on postweaning response but it would appear that there was no major age effect.

The plateau at day 4 was also observed in the studies of McCracken (1980), McCracken and Patterson (1981) and Robertson et al. (1985). It is probably related to the marked changes in gut histology and absorptive capacity noted in the immediate post-weaning period, although the mechanism remains to be elucidated. The considerable lag in attaining maximal intake (per kg or $\mathrm{kg} \mathbf{M}^{\mathbf{0 . 7 5}}$ ) is of interest. It is not clear that peak values had been achieved in either experiment within the 16- or 22-day periods. It is concluded that a detailed study of factors such as rate of passage, peptide hormone secretions and changes in gut histology during the period 2 to 3 weeks post weaning could yield valuable insights into the factors limiting voluntary food intake.

\section{REFERENCES}

McCracken, K. J. 1980. An integrated two-diet feeding regimen up to $30 \mathrm{~kg}$ body weight for pigs weaned at $10 \mathrm{~d}$. Record of Agricultural Research, Department of Agriculture for Northern Ireland 28: 103-105.

McCracken, K. J. and Patterson, D. C. 1981. Effect of dried skim milk/raw cereal proportions in diets for pigs weaned at 15 days, on food intake and growth up to $35 \mathrm{~d}$ and on diet digestibility. Animal Production 32: 397 (Abstr.).

MCCRACKEN, K. J. and Gray, R. 1984. Further studies on the heat production and effective lower critical temperature of early-weaned pigs under commercial conditions of feeding and management. Animal Production 39: 283-290.

Robertson, A. M., Clarke, J. J. and Bruce, J. M. 1985. Observed energy intake of weaned piglets and its effects on temperature requirements. Animal Production 40: 475-480. 